\title{
Promotion of Seedling Growth and Production of Wheat by Using Trichoderma spp.
}

\author{
Jessica B. de Oliveira ${ }^{1}$, Paulo Henrique P. C. Muniz ${ }^{1}$, Gustavo Henrique S. Peixoto ${ }^{1}$, Thiago A. S. de Oliveira ${ }^{2}$, \\ Elizabeth A. A. Duarte ${ }^{3}$, Fabrício Rodrigues ${ }^{1} \&$ Daniel Diego C. Carvalho ${ }^{1}$ \\ ${ }^{1}$ Universidade Estadual de Goiás, Ipameri, Goiás, Brazil \\ ${ }^{2}$ Universidade Estadual de Feira de Santana, Feira de Santana, Bahia, Brazil \\ ${ }^{3}$ Universidade Federal do Recôncavo da Bahia, Cruz das Almas, Bahia, Brazil \\ Correspondence: Daniel Diego C. Carvalho, Universidade Estadual de Goiás, Rodovia GO 330, km 241, Anel \\ Viário, Setor Universitário, 75780-000, Ipameri, Goiás, Brazil. Tel: 55-64-3491-1556. E-mail: \\ daniel.carvalho@ueg.br
}

Received: April 26, 2018

doi:10.5539/jas.v10n8p267

\author{
Accepted: June 4, $2018 \quad$ Online Published: July 15, 2018 \\ URL: https://doi.org/10.5539/jas.v10n8p267
}

\begin{abstract}
The fungus Trichoderma spp. is known due to its versatility for promoting crop growth and grain yield, improving the nutrient absorption and increasing the grain yield. The objective of this work was to evaluate commercial strains of Trichoderma spp. and an organomineral fertilizer in the early growth promotion and grain yield of wheat plants. Thus, wheat seeds cv. BRS 264 were treated with $2 \mathrm{~mL}$ of a Trichoderma suspension (2.5 $\times 10^{8}$ conidia $\mathrm{mL}^{-1}$ per $100 \mathrm{~g}$ seed) and submitted to growth in laboratory until 8 days after sowing (DAS). In the greenhouse experiment, the seeds were sown in an $8 \mathrm{~L}$ pot, which received $4.0 \times 10^{8}$ conidia of Trichoderma per pot. In both evaluations were: percentage of germination (PG), root length (RL), shoot length (SL), total length (TL), fresh root mass (FRM), fresh shoot mass (FSM), total fresh mass (TFM), dry root mass (DRM), dry shoot mass (DSM), total biomass (BIO), root mass ratio (RMR), shoot mass ratio (SMR) and aerial part/root system ratio $(\mathrm{AP} / \mathrm{RS})$. In the greenhouse experiment, paniculation and grain yield were evaluated at $110 \mathrm{DAS}$. The treatments T. harzianum ESALQ 1306 and T. asperellum URM5911 were considered satisfactory, since they provided grain yield superior to 2,000 $\mathrm{kg} \mathrm{ha}^{-1}$. In addition, T. harzianum ESALQ 1306 provided the best results for PG, RL, SL, TL, FRM, FSM, TFM, DRM, DSM and BIO under greenhouse conditions. The reduced biomass allocation to the root system in seedlings treated with Trichoderma ssp. occurred in the laboratory, which was confirm in greenhouse.
\end{abstract}

Keywords: biocontrol agents, humic acid, Triticum aestivum

\section{Introduction}

The wheat (Triticum aestivum L.) is considered extremely important for the sustainability of small and medium-sized properties in the south region of Brazil, being highly integrated in rotation and succession schemes with soybean and corn crops in the no-tillage crop system, ensuring the economic flow and the sustainability of the property (Camargo et al., 2004). In Brazil, about 11 million tons of wheat are consumed per year, according to the Companhia Nacional de Abastecimento (CONAB, 2018).

The use of plant growth promoting microorganisms has been currently an important tool for agricultural. In this sense, the rhizospheric interactions between plants and microorganisms are determinants and fundamental factors for plant health, productivity and soil fertility (Souza et al., 2015). The interaction occurs through the roots of plants that have the ability to synthesize metabolites that are recognized by microorganisms that, in response, produce signals that promote the initiation of microbial colonization (Berg, 2009). In addition, plant roots also have the ability to secrete sucrose as a food source providing the occurrence of colonization by microorganisms (Druzhinina et al., 2011; Vargas et al., 2011). Among the microorganisms that associate with the plants rhizosphere, Trichoderma species are common filamentous fungi in the soil, with some strains are capable of establishing beneficial relationships with plants (Harman et al., 2004; Contreras-Cornejo et al., 2014).

The use of the seed treatment technique may be a viable alternative for wheat seedlings become promising and provide better yields (Hossen et al., 2014). In the specific case, Trichoderma spp. can reduce the period of 
growth and, therefore, shorten the phase of seedlings; increase germination percentage and precocity, plant height, root development, shoot dry mass and leaf number; increasing the yield of the crop and improving plant vigor in biotic and abiotic stresses (Hajieghrari, 2010; Chagas et al., 2017). In additions, plant growth promotion by using Trichoderma results from rhizosphere colonization (rhizocompetence) and production of growth-stimulating substances (Mathivanan et al., 2005), as well as the solubilization of nutrients present in the regions neighboring the roots, making them assimilable (Harman et al., 2004). In another investigation, Contreras-Cornejo et al. (2009) suggest that Trichoderma spp. induces the growth promotion by a fungal auxin-dependent mechanism.

Different Trichoderma isolates have provide significant increases in the percentage and precocity of germination, as well as increasing growth and productivity of agricultural crops inoculated with this bioagent, as observed in maize (Zea mays), bean (Phaseolus vulgaris), cowpea beans (Vigna unguiculata), chickpea (Cicer arietinum), tomato (Solanum lycopersicum), tobacco (Nicotiana tabacum) and lettuce (Lactuca sativa) (Diniz et al., 2006; Chacon et al., 2007; Hoyos-Carvajal et al., 2009; Carvalho et al., 2011; Chagas Junior et al., 2014).

The insertion of Trichoderma spp. in nutrient-poor soils would act as a biofertilizer for their ability to solubilize these compounds by increasing crop productivity (Benítez et al., 2004). Such an insertion is highly desirable, because besides the benefits described, it is possible to reduce or eliminate the use of chemical fertilizers, which from the point of view of sustainable agricultural production, cause damages to the environment (Azarmi et al., 2011). However, few studies have addressed the potential of commercial strains of Trichoderma to promote plant growth. The objective of this work was to evaluate commercial strains of Trichoderma spp. in promoting the growth and productivity of wheat plants.

\section{Method}

\subsection{Commercial Strains}

The commercial strains were: Trichoderma harzianum IBLF 006 WP (Ecotrich WP; Ballagro Agro Tecnologia Ltda., Piracaia, SP, Brazil), Trichoderma harzianum IBLF 006 SC (Predatox SC, Ballagro Agro Tecnologia Ltda., Piracaia, SP, Brazil), Trichoderma harzianum ESALQ 1306 (Trichodermil, Koppert Biological Systems, Piracicaba, SP, Brazil), Trichoderma asperellum URM 5911 (Quality WG, BioControle Farroupilha Ltda, Patos de Minas, MG, Brazil) and an organomineral fertilizer (Qualytus SCP; N water-soluble $19.05 \mathrm{~g} / \mathrm{L}, \mathrm{P}_{2} \mathrm{O}_{5}$ water-soluble $38.10 \mathrm{~g} / \mathrm{L}, \mathrm{K}_{2} \mathrm{O}$ water-soluble $16.51 \mathrm{~g} / \mathrm{L}$, organic $\mathrm{C} 165.1 \mathrm{~g} / \mathrm{L}$ and $\mathrm{Zn}$ water-soluble $12.74 \mathrm{~g} / \mathrm{L}$; Rhal Indústria e Comércio de Produtos Agrícolas Ltda, Criciúma, SC, Brazil).

\subsection{Wheat Seedling Growth by the Treatment of Seeds With Trichoderma spp.}

Wheat seeds cv. BRS 264 (recommended for cultivation at Midwest Brazillian region) were treated with $2 \mathrm{~mL}$ of Trichoderma suspension $\left(2.5 \times 10^{8}\right.$ conidia $\mathrm{mL}^{-1}$ per $100 \mathrm{~g}$ of seeds) (Carvalho et al., 2014). Thus, each treatment had four replicates of 50 seeds (total of 200 seeds/treatment). After the treatment, the seeds were distributed on 2 germinating paper sheets, covered with a third sheet and then placed in a germinator (Logen Scientific ${ }^{\circledR}$ ) at the Seeds Laboratory in Universidade Estadual de Goiás (UEG), at $25^{\circ} \mathrm{C}$, during eight days. A treatment without Trichoderma inoculation and a treatment with organomineral fertilizer Qualytus SCP (at $8 \mu \mathrm{L}$ for each 100 seeds) were added as negative and positive control, respectively.

The evaluations were: percentage of germination (PG), which was obtianed by the count of normal seedlings (absence of necrosis and pathogen on the seedlings, seminal and secondary roots with no deformations and discounting the dead seeds), root length (RL), shoot legth (SL), total length ( $T L=R L+S L)$, root fresh mass (RFM), shoot fresh mass (SFM), total fresh mass (TFM = RFM + SFM), root dry mass (RDM), shoot dry mass $(\mathrm{SDM})$, total dry mass $(\mathrm{BIO}=\mathrm{RDM}+\mathrm{SDM})$, root mass ratio $(\mathrm{RMR}=\mathrm{RDM} / \mathrm{BIO})$, shoot mass ratio $(\mathrm{SMR}=$ $\mathrm{SDM} / \mathrm{BIO})$ and aerial part/root system ratio $(\mathrm{AP} / \mathrm{RS}=\mathrm{SDM} / \mathrm{RDM})$.

To obtain the RDM and SDM, the roots and aerial parts were detached and dried, separately, in a drying oven at $72{ }^{\circ} \mathrm{C}$ until the constant dry mass to obtain its values in milligrams.

\subsection{Production of Wheat in Greenhouse by Soil Treated With Trichoderma spp.}

The experiment was carried out in a greenhouse at UEG, Campus Ipameri $\left(17^{\circ} 43^{\prime} 00.38^{\prime \prime} \mathrm{S}, 48^{\circ} 08^{\prime} 40.96^{\prime \prime} \mathrm{W}, 796\right.$ $\mathrm{m}$ ), during 2016. For the experiment installation the soil used in the pots was corrected with calcareous according to Pires et al. (2011). The $8.0 \mathrm{~L}$ plastic pots $(0.23 \mathrm{~m}$ diameter) were filled with Yellow Red Latosol, according to the criteria described by Embrapa (2013). Subsequently, $8 \mathrm{~mL}$ of Trichoderma suspension was spread on each soil pot using a hand sprayer $(550 \mathrm{~mL})$, totaling $4.0 \times 10^{8}$ conidia per plastic pot. Immediately after spraying, BRS 264 wheat seeds were manually seeded (10 seeds per pot). The experiment was arranged in a completely randomized design (CRD) with eight replicates (pots) for each treatment (commercial strain of 
Trichoderma spp.). For comparison purposes, a treatment without Trichoderma inoculation and organomineral fertilizer Qualytus SCP (at $8 \mu \mathrm{L}$ for each 100 seeds) were added as negative and positive control, respectively.

The percentage of germination (PG) was verified at eight days after the sowing (DAS), estimating the number of plants emerged per pot. After $20 \mathrm{DAS}$, it was done a thinning, leaving 5 plants per pot. At 110 DAS, the grains harvest was carried out using the five plants from each pot wherein the moisture grain content was around $13 \%$, and then, it was measured the grain yield $\left(\mathrm{kg} \mathrm{ha}^{-1}\right)$. The paniculation and the growth components mentioned above (RL, SL, TL, RFM, SFM, TFM, RDM, SDM, BIO, RMR, SMR and AP/RS) were eavaluated.

To obtain the RDM and SDM, the roots and aerial parts were detached and dried, separately, in a drying oven at $72{ }^{\circ} \mathrm{C}$ until the constant dry mass to obtain its values in milligrams. Cultural practices up to 110 DAS were carried out according to Pires et al. (2011).

\subsection{Statistics Analysis}

The data concerining the experiments were subjected to variance analysis (ANOVA) and to Scott-Knott test (P $\leq$ 0.05), using the software SISVAR 5.3 (Ferreira, 2011).

\section{Results}

\subsection{Wheat Seedling Growth by the Treatment of Seeds With Trichoderma spp.}

Regarding the percentage of germination (PG), the strain T. asperellum URM 5911 was superior to the other treatments, providing $93.50 \%$ of PG. In sequence, the other strains and the organomineral fertilizer were superior to the negative control (85.50\%), with PG values ranging from 81.50 to $92.00 \%$ (Table 1 ). When evaluating the lengths, the strain $T$. asperellum URM 5911 presented root length $(\mathrm{RL}=7.39 \mathrm{~cm})$, shoot length $(\mathrm{SL}=10.55 \mathrm{~cm})$ and total length $(\mathrm{TL}=17.94 \mathrm{~cm})$ higher than the other treatments, whose RL, SL and TL values ranged from 2.90 to $7.22 \mathrm{~cm}, 5.66$ to $9.91 \mathrm{~cm}$ and 8.59 to $17.13 \mathrm{~cm}$, respectively. The negative control had the lowest RL, SL and TL values, which were $2.40 ; 4.35$ and $6.75 \mathrm{~cm}$, respectively.

Table 1. Percentage of germination percentage (PG), root length (RL), shoot length (SL), total length (TL), root fresh mass (RFM), shoot fresh mass (SFM) and total fresh mass (TFM) of wheat seedlings cv. BRS 264 treated with commercial stains of Trichoderma spp. Ipameri, Goiás, Brazil, $2017^{(1)}$

\begin{tabular}{llllllll}
\hline Treatment & PG $(\%)^{(2)}$ & RL $(\mathrm{cm})$ & SL $(\mathrm{cm})$ & TL $(\mathrm{cm})$ & RFM $(\mathrm{g})$ & SFM $(\mathrm{g})$ & TFM $(\mathrm{g})$ \\
\hline T. harzianum IBLF006 WP & $88.50 \mathrm{c}$ & $2.90 \mathrm{~d}$ & $5.71 \mathrm{~d}$ & $8.61 \mathrm{~d}$ & $14.29 \mathrm{c}$ & $22.99 \mathrm{c}$ & $37.28 \mathrm{c}$ \\
T. harzianum IBLF006 SC & $89.50 \mathrm{c}$ & $3.69 \mathrm{c}$ & $6.90 \mathrm{c}$ & $10.59 \mathrm{c}$ & $17.37 \mathrm{~b}$ & $31.40 \mathrm{~b}$ & $48.77 \mathrm{~b}$ \\
T. harzianum ESALQ1306 & $92.00 \mathrm{~b}$ & $7.22 \mathrm{~b}$ & $9.91 \mathrm{~b}$ & $17.13 \mathrm{~b}$ & $20.33 \mathrm{a}$ & $43.10 \mathrm{a}$ & $63.43 \mathrm{a}$ \\
T. asperellum URM 5911 & $93.50 \mathrm{a}$ & $7.39 \mathrm{a}$ & $10.55 \mathrm{a}$ & $17.94 \mathrm{a}$ & $20.85 \mathrm{a}$ & $43.10 \mathrm{a}$ & $63.95 \mathrm{a}$ \\
Organomineral Fertilizer & $81.50 \mathrm{~d}$ & $2.93 \mathrm{~d}$ & $5.66 \mathrm{~d}$ & $8.59 \mathrm{~d}$ & $14.41 \mathrm{c}$ & $22.39 \mathrm{~d}$ & $36.80 \mathrm{c}$ \\
Control & $85.50 \mathrm{e}$ & $2.40 \mathrm{e}$ & $4.35 \mathrm{e}$ & $6.75 \mathrm{e}$ & $11.93 \mathrm{~d}$ & $18.88 \mathrm{e}$ & $30.81 \mathrm{~d}$ \\
CV $(\%)$ & 1.06 & 11.05 & 7.45 & 6.61 & 2.32 & 1.22 & 1.40 \\
\hline
\end{tabular}

Note. ${ }^{(1)}$ Means followed by the same lowercase letter in the same columns do not statistically differ each other by the Scott Knott test $(\mathrm{P} \leq 0.05) .{ }^{(2)}$ Percentage of emergence at 8 days after sowing.

Concerning to the fresh mass, the strains T. harzianum ESALQ 1306 and T. asperellum URM 5911 were superior to the other treatments, presenting RFM of 20.33 and $20.85 \mathrm{mg}$, SFM of $43.10 \mathrm{mg}$ and TFM of 63.43 and 63.95 $\mathrm{mg}$, respectively (Table 2). Once again, the negative control showed the lowest values, which were $11.93,18.88$ and $30.81 \mathrm{mg}$ for RFM, SFM and TFM, respectively. As for dry matter, the strain T. asperellum URM 5911 was superior to the others $(\mathrm{RDM}=4.86 \mathrm{mg}, \mathrm{SDM}=8.39 \mathrm{mg}$ and $\mathrm{BIO}=13.25 \mathrm{mg})$. The other Trichoderma strains, although inferior to T. asperellum URM 5911, were superior to the negative control, which had the lowest dry mass values: 1.51, 2.57 and $4.08 \mathrm{mg}$ for RDM, SDM and BIO, respectively. In terms of the reasons, the organomineral fertilizer was superior to the other treatments as to RMR, which was 0.42 , while for the other treatments the value was 0.36 and 0.37 . In an opposite way, the organomineral fertilizer had SMR of 0.58, which was lower than the other treatments (SMR of 0.64 and 0.63 ), as well as the AP/RS, which was 1.41 , while for the other treatments the AP/RS was superior, ranging from 1.69 to 1.77 . 
Table 2. Root dry mass (RDM), shoot dry mass (SDM), total dry mass (BIO), root mass ratio (RMR), shoot mass ratio (SMR) and aerial part/root system ratio (AP/RS) of wheat seedlings cv. BRS 264 treated with commercial stains of Trichoderma spp. Ipameri, Goiás, Brazil, $2017^{(1)}$

\begin{tabular}{lllllll}
\hline Treatment & RDM $(\mathrm{g})$ & SDM $(\mathrm{g})$ & $\mathrm{BIO}(\mathrm{g})^{(2)}$ & $\mathrm{RMR}^{(3)}$ & $\mathrm{SMR}^{(4)}$ & $\mathrm{AP}^{2} \mathrm{RS}^{(5)}$ \\
\hline T. harzianum IBLF006 WP & $2.20 \mathrm{~d}$ & $3.89 \mathrm{c}$ & $6.09 \mathrm{~d}$ & $0.36 \mathrm{~b}$ & $0.64 \mathrm{a}$ & $1.76 \mathrm{a}$ \\
T. harzianum IBLF006 SC & $2.84 \mathrm{c}$ & $5.02 \mathrm{~b}$ & $7.86 \mathrm{c}$ & $0.36 \mathrm{~b}$ & $0.64 \mathrm{a}$ & $1.76 \mathrm{a}$ \\
T. harzianum ESALQ1306 & $4.51 \mathrm{~b}$ & $7.99 \mathrm{a}$ & $12.50 \mathrm{~b}$ & $0.36 \mathrm{~b}$ & $0.64 \mathrm{a}$ & $1.77 \mathrm{a}$ \\
T. asperellum URM 5911 & $4.86 \mathrm{a}$ & $8.39 \mathrm{a}$ & $13.25 \mathrm{a}$ & $0.36 \mathrm{~b}$ & $0.64 \mathrm{a}$ & $1.72 \mathrm{a}$ \\
Organomineral Fertilizer & $2.26 \mathrm{~d}$ & $3.18 \mathrm{~d}$ & $5.44 \mathrm{e}$ & $0.42 \mathrm{a}$ & $0.58 \mathrm{~b}$ & $1.41 \mathrm{~b}$ \\
Control & $1.51 \mathrm{e}$ & $2.57 \mathrm{e}$ & $4.08 \mathrm{f}$ & $0.37 \mathrm{~b}$ & $0.63 \mathrm{a}$ & $1.69 \mathrm{a}$ \\
CV $(\%)$ & 5.94 & 5.47 & 4.61 & 4.07 & 2.45 & 6.29 \\
\hline
\end{tabular}

Note. ${ }^{(1)}$ Means followed by the same lowercase letter in the same columns do not statistically differ each other by the Scott Knott test $(\mathrm{P} \leq 0.05) .{ }^{(2)} \mathrm{BIO}=\mathrm{RDM}+\mathrm{SDM} .{ }^{(3)}$ Root mass ratio $(\mathrm{RMR}=\mathrm{RDM} / \mathrm{BIO}) .{ }^{(4)}$ Shoot mass ratio $(\mathrm{SMR}=\mathrm{SDM}) / \mathrm{BIO}) .{ }^{(5)}$ Aerial part/root system ratio $\left.(\mathrm{AP} / \mathrm{RS}=\mathrm{SDM}) / \mathrm{RDM}\right)$.

\subsection{Production of Wheat in Greenhouse by Soil Treated With Trichoderma spp.}

Contrasting the seedling experiment, all Trichoderma strains showed PG (95 to 100\%) higher than the other treatments, whose PG values were 90 and $85 \%$ for the organomineral fertilizer and control, respectively (Table 3). When comparing the lengths, T. harzianum ESALQ 1306 showed root length $(\mathrm{RL}=19.44 \mathrm{~cm})$, shoot length $(\mathrm{SL}=55.54 \mathrm{~cm})$ and total length $(\mathrm{TL}=74.98 \mathrm{~cm})$ higher than the other treatments, whose RL, SL and TL values ranged from 6.71 to $7.92 \mathrm{~cm}, 30.30$ to $46.93 \mathrm{~cm}$ and 37.01 to $54.81 \mathrm{~cm}$, respectively. The negative control showed the lowest RL, SL and TL values, which were $5.13,23.70$ and $28.83 \mathrm{~cm}$, respectively.

Table 3. Percentage of germination (PG), root length (RL), shoot length (SL), total length (TL), root fresh mass (RFM), shoot fresh mass (SFM) and total fresh mass (TFM) of wheat plants cv. BRS 264 in greenhouse by soil treated with suspension of Trichoderma spp., Ipameri, Goiás, Brazil, 2017 ${ }^{(1)}$

\begin{tabular}{llllllll}
\hline Treatment & PG $(\%)^{(2)}$ & RL $(\mathrm{cm})$ & SL $(\mathrm{cm})$ & TL $(\mathrm{cm})$ & RFM $(\mathrm{g})$ & SFM $(\mathrm{g})$ & TFM $(\mathrm{g})$ \\
\hline T. harzianum IBLF006 WP & $95.00 \mathrm{a}$ & $7.75 \mathrm{~b}$ & $42.99 \mathrm{c}$ & $50.74 \mathrm{c}$ & $0.71 \mathrm{c}$ & $1.76 \mathrm{c}$ & $2.47 \mathrm{c}$ \\
T. harzianum IBLF006 SC & $100.00 \mathrm{a}$ & $7.92 \mathrm{~b}$ & $43.69 \mathrm{c}$ & $51.61 \mathrm{c}$ & $0.71 \mathrm{c}$ & $1.83 \mathrm{c}$ & $2.54 \mathrm{c}$ \\
T. harzianum ESALQ1306 & $100.00 \mathrm{a}$ & $19.44 \mathrm{a}$ & $55.54 \mathrm{a}$ & $74.98 \mathrm{a}$ & $1.71 \mathrm{a}$ & $4.61 \mathrm{a}$ & $6.32 \mathrm{a}$ \\
T. asperellum URM 5911 & $100.00 \mathrm{a}$ & $7.88 \mathrm{~b}$ & $46.93 \mathrm{~b}$ & $54.81 \mathrm{~b}$ & $1.18 \mathrm{~b}$ & $3.37 \mathrm{~b}$ & $4.55 \mathrm{~b}$ \\
Organomineral Fertilizer & $90.00 \mathrm{~b}$ & $6.71 \mathrm{c}$ & $30.30 \mathrm{~d}$ & $37.01 \mathrm{~d}$ & $0.60 \mathrm{c}$ & $1.32 \mathrm{~d}$ & $1.92 \mathrm{~d}$ \\
Control & $85.00 \mathrm{~b}$ & $5.13 \mathrm{~d}$ & $23.70 \mathrm{e}$ & $28.83 \mathrm{e}$ & $0.49 \mathrm{c}$ & $1.24 \mathrm{~d}$ & $1.73 \mathrm{~d}$ \\
CV $(\%)$ & 5.81 & 22.35 & 13.45 & 12.76 & 19.44 & 13.20 & 11.35 \\
\hline
\end{tabular}

Note. ${ }^{(1)}$ Means followed by the same lowercase letter in the same columns do not statistically differ each other by the Scott Knott test $(\mathrm{P} \leq 0.05)$. ${ }^{(2)}$ Percentage of emergence at 8 days after sowing.

Concerning to the fresh mass, as well as the seedlings experiment, T. harzianum ESALQ 1306 strain was superior to the other treatments, showing RFM of $1.71 \mathrm{~g}$, SFM of $4.61 \mathrm{~g}$ and TFM of $6.32 \mathrm{~g}$ (Table 4). In greenhouse, organomineral fertilizer and the control were similar and inferior to the others, presenting values of 0.60 and $0.49,1.32$ and $1.24 ; 1.92$ and 1.73 to RFM, SFM and TFM, respectively. As for the dry mass, $T$. harzianum ESALQ 1306 was superior than the others $(\mathrm{RDM}=1.28 \mathrm{~g}, \mathrm{SDM}=3.05 \mathrm{~g}$ and $\mathrm{BIO}=4.33 \mathrm{~g})$. The rest of the other Trichoderma strains, although lower than T. harzianum ESALQ 1306, were superior than control, which had the lowest dry mass values: 0.35 and $0.59 \mathrm{~g}$ to SDM and BIO, respectively. T. harzianum IBLF strains and organomineral fertilizer were similar to the control as to RDM. As regards ratios, the control was superior than the other treatments as to RMR, which was 0.41 , while for the other treatments the value ranged from 0.20 to 0.34 . On the other hand, the control presented $\mathrm{SMR}=0.59$, which was lower than the other treatments $(0.66$ to 0.80 ), as well as AP/RS, whose value was 1.43 , whereas for the other treatments were higher, ranging from 2.21 to 4.14 . 
Table 4. Root dry mass (RDM), shoot dry mass (SDM), total dry mass (BIO), root mass ratio (RMR), shoot mass ratio (SMR) and aerial part/root system ratio (AP/RS) of wheat plants cv. BRS 264 in greenhouse by soil treated with suspension of Trichoderma spp., Ipameri, Goiás, Brazil, $2017^{(1)}$

\begin{tabular}{lllllll}
\hline Treatment & RDM $(\mathrm{g})$ & $\mathrm{SDM}(\mathrm{g})$ & $\mathrm{BIO}(\mathrm{g})^{(2)}$ & $\mathrm{RMR}^{(3)}$ & $\mathrm{SMR}^{(4)}$ & $\mathrm{AP}^{(\mathrm{RS}}{ }^{(5)}$ \\
\hline T. harzianum IBLF006 WP & $0.34 \mathrm{c}$ & $1.40 \mathrm{c}$ & $1.74 \mathrm{c}$ & $0.20 \mathrm{~d}$ & $0.80 \mathrm{a}$ & $4.14 \mathrm{a}$ \\
T. harzianum IBLF006 SC & $0.34 \mathrm{c}$ & $1.23 \mathrm{c}$ & $1.57 \mathrm{c}$ & $0.22 \mathrm{~d}$ & $0.78 \mathrm{a}$ & $3.59 \mathrm{a}$ \\
T. harzianum ESALQ1306 & $0.28 \mathrm{a}$ & $3.05 \mathrm{a}$ & $4.33 \mathrm{a}$ & $0.30 \mathrm{c}$ & $0.70 \mathrm{~b}$ & $2.47 \mathrm{~b}$ \\
T. asperellum URM 5911 & $0.64 \mathrm{~b}$ & $2.08 \mathrm{~b}$ & $2.72 \mathrm{~b}$ & $0.24 \mathrm{~d}$ & $0.76 \mathrm{a}$ & $3.24 \mathrm{a}$ \\
Organomineral Fertilizer & $0.38 \mathrm{c}$ & $0.72 \mathrm{~d}$ & $1.10 \mathrm{~d}$ & $0.34 \mathrm{~b}$ & $0.66 \mathrm{c}$ & $2.21 \mathrm{~b}$ \\
Control & $0.24 \mathrm{c}$ & $0.35 \mathrm{e}$ & $0.59 \mathrm{e}$ & $0.41 \mathrm{a}$ & $0.59 \mathrm{~d}$ & $1.43 \mathrm{c}$ \\
CV $(\%)$ & 21.90 & 17.52 & 14.27 & 16.37 & 6.53 & 25.36 \\
\hline
\end{tabular}

Note. ${ }^{(1)}$ Means followed by the same lowercase letter in the same columns do not statistically differ each other by the Scott Knott test $(\mathrm{P} \leq 0.05) .{ }^{(2)} \mathrm{BIO}=\mathrm{RDM}+\mathrm{SDM} .{ }^{(3)}$ Root mass ratio $(\mathrm{RMR}=\mathrm{RDM} / \mathrm{BIO}) .{ }^{(4)}$ Shoot mass ratio $(\mathrm{SMR}=\mathrm{SDM}) / \mathrm{BIO}) .{ }^{(5)}$ Aerial part/root system ratio $\left.(\mathrm{AP} / \mathrm{RS}=\mathrm{SDM}) / \mathrm{RDM}\right)$.

Referring to the paniculation, T. harzianum ESALQ 1306 required the shortest number of days (36 days), followed by T. harzianum IBLF 006 and T. asperellum URM5911 (41 days) and the others needed more than 46 days (Table 5). Regarding grain yield, T. harzianum ESALQ 1306 was superior to the others $\left(2,751 \mathrm{~kg} \mathrm{ha}^{-1}\right)$, followed by $T$. asperellum URM5911 $\left(2,241 \mathrm{~kg} \mathrm{ha}^{-1}\right)$. Next, T. harzianum IBLF 006 produced around 1,650 kg $\mathrm{ha}^{-1}$, and finally, the control and the organomineral fertilizer, which had, 750 and $732 \mathrm{~kg} \mathrm{ha}^{-1}$, respectively.

Table 5. Wheat plants paniculation and grain yield in greenhouse by soil treated with suspension of Trichoderma spp., Ipameri, Goiás, Brazil, $2017^{(1)}$

\begin{tabular}{lll}
\hline Treatment & Paniculation (days) & Grain Yield $\left(\mathrm{kg} \mathrm{ha}^{-1}\right)$ \\
\hline T. harzianum IBLF 006 WP & $41.87 \mathrm{~b}$ & $1,629 \mathrm{c}$ \\
T. harzianum IBLF 006 SC & $46.87 \mathrm{c}$ & $1,656 \mathrm{c}$ \\
T. harzianum ESALQ 1306 & $36.00 \mathrm{a}$ & $2,751 \mathrm{a}$ \\
T. asperellum URM 5911 & $41.75 \mathrm{~b}$ & $2,241 \mathrm{~b}$ \\
Organomineral Fertilizer & $54.87 \mathrm{e}$ & $750 \mathrm{~d}$ \\
Control & $50.75 \mathrm{~d}$ & $732 \mathrm{~d}$ \\
CV $(\%)$ & 2.10 & 11.36 \\
\hline
\end{tabular}

Note. ${ }^{(1)}$ Means followed by the same lowercase letter in the same columns do not statistically differ each other by the Scott Knott test $(\mathrm{P} \leq 0.05)$.

\section{Discussion}

The main stages of germination are: (1) intense water absorption, (2) activation of metabolic processes and (3) growth and differentiation of tissues. The presence of hormones, promoters and growth inhibitors are fundamental for the physiological process of germination to occur (Ferreira \& Borghetti, 2004). As is known, the genus Trichoderma spp. Can to promote beneficial effects on germination and on seedling emergence, since the solubilized nutrients become available for root uptake (Hoyos-Carvajal et al., 2009). Other authors had verified strains of Trichoderma spp. increasing the percentage of germination of other grasses, such as maize and black oats (Luz, 2001; Shoresh et al., 2010; Machado, 2011). As for organomineral fertilizer, Aguiar et al. (2009) found an increase in the number of mitoses and lateral roots of grass seedlings, such as maize, suggesting that humic substances may accelerate the seed germination process.

There are two forms of soil borne microorganisms promoting plant growth: direct and indirect form. The first form is related with the production of hormones or analogous that influence the growth or plant development (Machado et al., 2011), or by supplementing their nutritional requirements with phosphate solubilization (Gravel et al., 2007). The indirect form comprises in the inhibition of plant pathogens (Silva et al., 2011; Gava \& Menezes, 2012). In the specific case of this work, wheat seeds cv. BRS 264 had low or no occurrence of pathogens that were harmful to germination, suggesting that the most probable mechanism to promote initial growth was by the direct form, that is, the production of hormones and vitamins that stimulate plant growth. In 
studies conducted by Gravel et al. (2007), Trichoderma spp. was confirmed as an indole-acetic acid (IAA) producer, promoting the growth of Solanum lycopersicum.

After seedlings experiment, T. asperellum URM 5911 highlighted in comparison to the others, and this may be related not only to the fact that it belongs to a different species, but the various factors that may interfere on this fungi, such as better temperature adaptability and moisture of the controlled environment in which the experiment was carried out. These physical factors are of fundamental importance for a strain to perform well (Akrami et al., 2011).

Regarding the accumulation of fresh mass in seedling experiment, T. asperellum URM 5911 and T. harzianum ESALQ 1306 were superior. The explanation for this fact can be found in the study by Chacón et al. (2007), which tomato plants inoculated with $T$. harzianum showed a greater proliferation of roots and, therefore, a greater increase in the fresh mass of the different parts of the plant. Harman et al. (2012) reports that the interaction of the fungus with the plant occurs due to changes in root architecture, increasing the surface area, modifying the plant physiology, resulting in greater photosynthetic efficiency.

For the reasons of the Table 2, the organomineral fertilizer presented better result as to RMR, that is, in a laboratory experiment, the seedlings obtained from seeds treated with the fertilizer increased the biomass allocation to the root system, probably due to the composition of the fertilizer, which is rich in macronutrients and stimulate the micronutrients absorption. In contrast, the reduced biomass allocation to the root system in seedlings treated with Trichoderma spp. occurred due to the high availability of water, daily, so that, there being no water restriction, the availability of resources for the formation of a deep and robust root system was not necessary (Guimarães et al., 2014). Consequently, the high AP/RS ratio of the seedlings treated with Trichoderma spp. occurred due to the intense allocation of biomass to the aerial part.

In the greenhouse experiment, the organomineral fertilizer and the control provided a PG lower than Trichoderma spp treatments. This fact may be related to the dose of fertilizer, since even though the dose used in this study was not toxic to the plant root, there is a very narrow limit in the interval corresponding to the ideal dose for the seeds treatment in each culture (Camargo et al., 2001). In addition, similarly, Vendruscolo et al. (2014), observed that doses of humic substances and other organomineral fertilizers in sorghum seeds had no effect on germination. Therefore, it is worth mentioning that, like the PG results verified in greenhouse or in field, the effects of the treatments are sometimes uncertain and depends on the employed dose, species tested and environmental conditions which the study was performed.

The T. asperellum URM 5911 strain, which had shown best length result in the laboratory, did not repeat this result in field, showing results lower than T. harzianum ESALQ 1306. An explanation for this event lies in the fact that the soil borne fungi behavior, such as Trichoderma, can be modified when it is evaluated in another environment (Akrami et al., 2011). These behavior differences, verified in vitro and in vivo, may be associated to the physical, chemical and environmental conditions, which they were submitted, since they are living organisms (Benítez et al., 2004).

Results corresponding to the superiority of T. harzianum ESALQ 1306 in the field (such as RFM, SFM, TFM, RDM, SDM and BIO) were expected, since after a Trichoderma strain established a relationship with the rhizosphere, these can stimulate plant growth (Akladious \& Abbas, 2012). This inference is valid, since $T$. harzianum ESALQ 1306 was reported by Carvalho et al. (2015b) colonizing soil under bean crops, whereas after fungal application, it was recovered from soil at the harvest showing populations ranging from 50 to $100 \mathrm{CFU} \mathrm{g}^{-1}$ soil. Furthermore, not only ability to colonize soil of the root region, but the plant growth promotion depends of the interaction between isolate and plant species and experiment conditions.

In the present study, attempts has been made to obtaining fresh mass of the plants in greenhouse. Although RFM is less frequent evaluated in scientific studies about plant growth promotion, the roots exploit a larger soil volume and are important in the process of adaptation of plants in environments with less nutrients (Hartwigsen \& Evans, 2000; Taiz \& Zeiger, 2013). In this regard, as many Trichoderma strains can aid in nutrients solubilization (Benítez et al., 2004), it was verified that T. harzianum ESALQ 1306 has potential to operate under aforementioned conditions. In greenhouse, organomineral fertilizer and control were inferior to the other treatments for RFM, SFM and TFM. This result confirms the premise that the optimal doses used for organomineral fertilizer are peculiar to each species studied (Vaughan \& Malcolm, 1985). Similarly, Nicchio et al. (2013), when applying organomineral fertilizer containing humic acid in corn seeds, did not promoted an increase of total fresh mass and total dry mass. Finally, the growth promotion depends on source, dose and plant species used (Pimenta et al., 2009). 
The negative control was superior to the other treatments for RMR, while was inferior for SMR and AP/RS. This result confirmed in field that Trichoderma spp. strains again reduced biomass allocation to the root system, differentiating that, once applied on the field, most of Trichoderma isolates interact with the plant at or around the roots, establishing a chemical and systemic communication, altering the expression of innumerable plant gens and may provide resistance to biotic and abiotic stresses, thus promoting growth (Druzhinina, 2012).

According to Albrecht et al. (2006), from emergency to ear formation in early wheat cultivation, it takes 50 days. In this context, T. harzianum ESALQ 1306 needed the less amount of days (36 days) for the panicles formation, evidencing the its ability to contributed to the precocity of the plant material. Such event becomes extremely important since a shorter crop cycle avoids greater exposure inclement weather and anticipates summer crop planting.

Concerning grain yield, T. harzianum ESALQ 1306 and T. asperellum URM5911 were considered satisfactory, since the average productivity in Brazil was estimated in 2,431 kg ha ${ }^{-1}$ in 2018 (CONAB, 2018). The other strains had grain yield lower than T. harzianum ESALQ 1306 and T. asperellum URM5911. However, these can not be ruled out, because not all the efficient bioagents in growth promotion have equal efficiency to control diseases (Carvalho et al., 2011; Carvalho et al., 2015a; Carvalho et al., 2015b). As regards organomineral fertilizer, it was verified that when applied at $8 \mu \mathrm{L}$ for each 100 seeds, it limited to give a good effect only in PG, not increasing grain yield.

\section{Conclusion}

Concerning to seedlings growth, T. asperellum URM 5911 stood out from the others, but this strain did not repeat their performance in the greenhouse experiments, showing growth values lower than T. harzianum ESALQ 1306.

T. harzianum ESALQ 1306 and T. asperellum URM5911 were considered satisfactory, since they provided grain yield superior to $2,000 \mathrm{~kg} \mathrm{ha}^{-1}$.

The reduced biomass allocation to the root system in seedlings treated with Trichoderma ssp. occurred in the laboratory, which was confirm in greenhouse.

The organomineral fertilizer, when applied to $8 \mu \mathrm{L} / 100$ seeds, was limited to provide a good effect in the PG.

\section{Acknowledgements}

The authors acknowledge the support provided by the Universidade Estadual de Goiás (UEG)/Pró-Projetos/Programas (Edital 031/2016, Processo 201600020011640), the Incentive Scholarship Program for Research and Scientific Production (PROBIP-UEG) and the companies Ballagro Agro Technology Ltda. and Rhal Industry and Commerce of agriculture products Ltda.

\section{References}

Aguiar, N. O., Canellas, L. P., Dobbss, L. B., Zandonadi, D. B., Olivares, F. L., \& Façanha, A. R. (2009). Distribuição de massa molecular de ácidos húmicos e promoção do crescimento radicular. Revista Brasileira de Ciência do Solo, 33(6), 1613-1623. https://doi.org/10.1590/S0100-06832009000600010

Akladious, A. S., \& Abbas, S. M. (2012). Application of Trichoderma harziunum T22 as a biofertilizer supporting maize growth. African Journal of Biotechnology, 11(35), 8672-8683. https://doi.org/10.5897/ AJB11.4323

Akrami, M., Golzary, H., \& Ahmadzadeh, M. (2011). Evaluation of different combinations of Trichoderma species for controlling Fusarium rot of lentil. African Journal of Biotechnology, 10(14), 2653-2658. https://doi.org/10.5897/AJB10.1274

Albrecht, J. C., Silva, M. S., Andrade, J. M. V., Scheeren, P. L., Trindade, M. G., Sobrinho, J. S., ... Yamanaka, C. H. (2006). Trigo BRS 264: Cultivar precoce com alto rendimento de grãos indicada para o Cerrado do Brasil Central (p. 174). Planaltina: Embrapa Cerrados.

Azarmi, R., Hajieghrari, B., \& Giglou, A. (2011). Effect of Trichoderma isolates on tomato seedling growth response and nutrient uptake. African Journal of Biotechnology, 10(31), 5850-5855. https://doi.org/10.5897/ AJB10.1600

Benítez, T., Rincón, A. M., Limón, M. C. L., \& Codón, A. C. (2004). Biocontrol Mechanisms of Trichoderma Strains, International Microbiology, 7(4), 249-260. 
Berg, G. (2009). Plant-microbe interactions promoting plant growth and health: Perspectives for controlled use of microorganisms in agriculture. Applied Microbiology and Biotechnology, 84(1), 11-18. https://doi.org/ $10.1007 / \mathrm{s} 00253-009-2092-7$

Camargo, C. E. O., Ferreira Filho, A. W. P., \& Salomon, M. V. (2004). Temperature and pH of the nutrient solution on wheat primary root growth. Scientia Agricola, 61(3), 313-318. https://doi.org/10.1590/S0103-90 162004000300013

Camargo, F. A. O., Zonta, E., Santos, G. A., \& Rossiello, R. O. P. (2001). Aspectos fisiológicos e caracterização da toxidez de ácidos orgânicos voláteis em plantas, Ciência Rural, 31(3), 523-529. https://doi.org/10.1590/ S0103-84782001000300029

Carvalho, D. D. C., Geraldine, A. M., Lobo Junior, M., \& Mello, S. C. M. (2015a). Biological control of white mold by Trichoderma harzianum in common bean under field conditions. Pesquisa Agropecuária Brasileira, 50(12), 1220-1224. https://doi.org/10.1590/S0100-204X2015001200012

Carvalho, D. D. C., Lobo Junior, M., Martins, I., Inglis, P. W., \& Mello, S. C. M. (2014). Biological control of Fusarium oxysporum f. sp. phaseoli by Trichoderma harzianum and its use for common bean seed treatment. Tropical Plant Pathology, 39(5), 384-391. https://doi.org/10.1590/S198256762014000500005

Carvalho, D. D. C., Mello, S. C. M., Lobo Junior, M., \& Geraldine, A. M. (2011). Biocontrol of seed pathogens and growth promotion of common bean seedlings by Trichoderma harzianum. Pesquisa Agropecuária Brasileira, 46(8), 822-828. https://doi.org/10.1590/S0100-204X2011000800006

Carvalho, D. D. C., Mello, S. C. M., Martins, I., \& Lobo Junior, M. (2015b). Biological control of fusarium wilt on common beans by in-furrow application of Trichoderma harzianum. Tropical Plant Pathology, 40, 375-381. https://doi.org/10.1007/s40858-015-0057-1

Chacón, M. R., Rodriguéz-Galan, O., Benitez, T., Sousa, S., Rey, M., Llobell, A., \& Delgado-Jarana, J. (2007). Microscopic and transcriptome analyses of early colonization of tomato roots by Trichoderma harzianum. International Microbiology, 10(1), 19-27. https://doi.org/10.2436/20.1501.01.4

Chagas Junior, A. F., Oliveira, A. G., Reis, H. B., Santos, G. R., Chagas, L. F. B., \& Miller, L. O. (2014). Eficiência da inoculação combinada de rizóbio e Trichoderma spp. em diferentes cultivares de feijão-caupi (Vigna unguiculata) no cerrado (Savana Brasileira). Revista de Ciências Agrárias, 37(1), 20-28.

Chagas, L. F. B., Chagas Junior, A. F., Soares, L. P., \& Fidelis, R. R. (2017). Trichoderma na promoção do crescimento vegetal. Revista de Agricultura Neotropical, 4(3), 97-102.

CONAB (Companhia Nacional de Abastecimento). (2018). Acompanhamento Da Safra Brasileira de Grãos. Retrieved from http://www.conab.gov.br/OlalaCMS/uploads/arquivos/18_03_13_14_15_33_grao_marco_ 2018.pdf

Contreras-Cornejo, H. A., Macías-Rodríguez, L., Alfaro-Cuevas, R., \& López-Bucio, J. (2014). Trichoderma spp. improve growth of Arabidopsis seedlings under salt stress through enhanced root development, osmolite production, and $\mathrm{Na}^{+}\left(^{+}\right.$) elimination through root exudates. Molecular Plant-Microbe Interactions, 27(1), 503-514. https://doi.org/10.1094/MPMI-09-13-0265-R

Contreras-Cornejo, H. A., Macías-Rodríguez, L., Cortés-Penagos, C., \& López-Bucio, J. (2009). Trichoderma virens, a plant beneficial fungus, enhances biomass production and promotes lateral root growth through an auxin-dependent mechanism in Arabidopsis. Plant Physiology, 149(1), 1579-1592. https://doi.org/10.1104/ pp.108.130369

Diniz, K. A., Oliveira, J. A. O., Guimarães, R. M., Carvalho, M. L. M., \& Machado, J. C. (2006). Incorporação de microrganismos, aminoácidos, micronutrientes e reguladores de crescimento em sementes de alface pela técnica de peliculização. Revista Brasileira de Sementes, 28(3), 37-43. https://doi.org/10.1590/S0101-31222 006000300006

Druzhinina, I. S., Seidl-Seiboth, V., Herrera-Estrella, A., Horwitz, B. A., Kenerley, C. M., Monte, E., ... Kubicek, C. P. (2011). Trichoderma: The genomics of opportunistic success. Nature Reviews Microbiology, 9(1), 896-896. https://doi.org/10.1038/nrmicro2689

Druzhinina, I. S., Shelest, E., \& Kubicek, C. P. (2012). Novel traits of Trichoderma predicted through the analysis of its secretome. FEMS Microbiology Letters, 337(1), 01-09. https://doi.org/10.1111/j.1574-6968. 2012.02665.x

EMBRAPA. (2013). Sistema Brasileiro de Classificação de Solos. Brasília: Embrapa-SPI. 
Ferreira, A. G., \& Borghetti, F. (2004). Germinação: do básico ao aplicado. Artmed: Porto Alegre.

Ferreira, D. F. (2011). Sisvar: A computer statistical analysis system. Ciência e Agrotecnologia, 35(6), 1039-1042. https://doi.org/10.1590/S1413-70542011000600001

Gava, C. A. T., \& Menezes, M. E. L. (2012). Eficiência de isolados de Trichoderma spp. no controle de patógenos de solo em meloeiro amarelo. Revista Ciência Agronômica, 43(4), 633-640. https://doi.org/ $10.1590 / \mathrm{s} 1806-66902012000400003$

Gravel, V., Antoun, H., \& Tweddell, R. J. (2007). Growth stimulation and fruit yield improvement of greenhouse tomato plants by inoculation with Pseudomonas putida or Trichoderma atroviride: Possible role of índole acetic acid (IAA). Soil Biology \& Biochemistry, 39(8), 1968-1977. https://doi.org/10.1016/j.soilbio.2007. 02.015

Guimarães, G. R., Pereira, F. S., Matos, F. S., Mello, S. C. M., \& Carvalho, D. D. C. (2014). Supression of seed borne Cladosporium herbarum on common bean seed by Trichoderma harzianum and promotion of seedling development. Tropical Plant Pathology, 39(5), 401-406, 2014. https://doi.org/10.1590/S1982-5676 2014000500007

Hajieghrari, B. (2010). Effects of some Iranian Trichoderma isolates on maize seed germination and seedling vigor. African Journal of Biotechnology, 9, 4342-4347.

Harman, G. E., Herrera, A. H. E., Horwitz, B. A., \& Lorito, M. (2012). Special issue: Trichoderma - from Basic Biology to Biotechnology. Microbiology, 158(1), 01-02. https://doi.org/10.1099/mic.0.056424-0

Harman, G. E., Howell, C. R., Viterbo, A., Chet, I., \& Lorito, M. (2004). Trichoderma species-Opportunistic, avirulent plant symbionts. Nature Reviews Microbiology, 2(1), 43-56. https://doi.org/10.1038/nrmicro797

Hartwigsen, J., \& Evans, M. R. (2000). Humic acid seed and substrate treatments promote seedling root development. Hortscience, 35(7), 1231-1233.

Hossen, D. D. C., Corrêa Júnior, E. D. S., Guimarães, S., Nunes, U. R., \& Galon, L. (2014). Chemical treatment of wheat seeds. Pesquisa Agropecuária Tropical, 44(1), 104-109. https://doi.org/10.1590/S1983-4063 2014000100014

Hoyos-Carvajal, L., Orduz, S., \& Bissett, J. (2009). Growth stimulation in bean (Phaseolus vulgaris L.) by Trichoderma. Biological Control, 51(3), 409-416. https://doi.org/10.1016/j.biocontrol.2009.07.018

Luz, W. C. (2001). Efeito de bioprotetores em patógenos de sementes e na emergência e rendimento de grãos de milho. Fitopatologia Brasileira, 26, 16-20. https://doi.org/10.1590/S0100-41582001000100003

Machado, R. G., Sá, E. L. S., Damasceno, R. G., Hahn, L., Almeida, D., Moraes, T., ... Reartes, D. S. (2011). Promoção de crescimento de Lotus corniculatus L. e Avena strigosa Schreb pela inoculação conjunta de Trichoderma harzianum e rizóbio. Ciência e Natura, 33(2), 111-126. https://doi.org/10.5902/2179460 X9365

Mathivanan, N., Prabavathy, V. R., \& Vijayanandraj, V. R. (2005). Application of talc formulations of Pseudomonas fluorescens Migula and Trichoderma viride Pers. ex SF Gray decrease the sheath blight disease and enhance the plant growth and yield in rice. Journal of Phytopathology, 153(11-12), 697-701. https://doi.org/10.1111/j.1439-0434.2005.01042.x

Nicchio, B., Boer, C. A., Siqueira, T. P., Vasconcelos, A. C. P., Rezende, W. S., \& Lana, R. M. Q. (2013). Ácido húmico e bioativador no tratamento de sementes de milho. Journal of Agronomic Sciences, 2(2), 61-73.

Pimenta, A. S., Santana, J. A. S., Anjos, R. M., Benites, V. M., \& Araújo, S. O. (2009). Caracterização de ácidos húmicos produzidos a partir de carvão vegetal de duas espécies florestais do semi-árido: Jurema preta (Mimosa tenuiflora) e Pereiro (Aspidosperma pyrifolium). Revista Verde de Agroecologia e Desenvolvimento Sustentável, 4(4), 01-11.

Pires, J. L. F., Vargas, L., \& Cunha, G. R. (2011). Trigo no Brasil: bases para produção competitiva e sustentável. Passo Fundo, RS: Embrapa Trigo.

Shoresh, M., Mastouri, F., \& Harman, G. E. (2010). Induced systemic resistance and plant responses to fungal biocontrol agents. Annual Review of Phytopathology, 48, 21-43. https://doi.org/10.1146/annurev-phyto073009-114450 
Silva, V. N., Guzzo, S. D., Lucon, C. M. M., \& Harakava, R. (2011). Promoção de crescimento e indução de resistência à antracnose por Trichoderma spp. em pepineiro. Pesquisa Agropecuária Brasileira, 46(12), 1609-1618. https://doi.org/10.1590/S0100-204X2011001200005

Souza, R., Ambrosini, A., \& Passaglia, L. M. (2015). Plant growth-promoting bacteria as inoculants in agricultural soils. Genetics and Molecular Biology, 38(1), 401-419. https://doi.org/10.1590/S1415-4757384 20150053

Taiz, L., \& Zeiger, E. (2013). Fisiologia vegetal. Porto Alegre, RS: Artmed.

Vargas, W. A., Crutcher, F. K., \& Kenerley, C. M. (2011). Functional characterisation of a plant-like sucrose transporter from the beneficial fungus Trichoderma virens. Regulation of the symbiotic association with plants by sucrose metabolism inside the fungal cells. New Phytologist, 189(1), 777-789. https://doi.org/ 10.1111/j.1469-8137.2010.03517.x

Vaughan, D., \& Malcolm, R. E. (1985). Influence of humic substances on growth and physiological processes. Soil organic matter and biological activity (pp. 37-75). Netherlands: Springer. https://oi.org/10.1007/ 978-94-009-5105-1_2

Vendruscolo, E. P., Santos, O. F., \& Alves, C. Z. (2014). Substâncias húmicas na qualidade fisiológica de sementes de sorgo. Journal of Agronomic Sciences, 3, 169-177.

\section{Copyrights}

Copyright for this article is retained by the author (s), with first publication rights granted to the journal.

This is an open-access article distributed under the terms and conditions of the Creative Commons Attribution license (http://creativecommons.org/licenses/by/4.0/). 